\begin{tabular}{|l|l|}
\hline \multicolumn{2}{|c|}{ Toppan Best-set Premedia Limited } \\
\hline Journal Code: ADD & Proofreader: Mony \\
\hline Article No: ADD12232 & Delivery date: 14 May 2013 \\
\hline Page Extent: 7 & \\
\hline
\end{tabular}

\title{
Gambling in Spain: update on experience, research and policy
}

\author{
Susana Jiménez-Murcia ${ }^{1,2,3}$, Fernando Fernández-Aranda ${ }^{1,2,3}$, Roser Granero ${ }^{3,4}$ \& \\ $\square$ Jose Manuel Menchón ${ }^{1,2,5}$
}

Pathological Gambling Unit, Department of Psychiatry, Bellvitge University Hospital-IDIBELL, Barcelona, Spain,' Clinical Science Department, School of Medicine, University of Barcelona, Barcelona, Spain, ${ }^{2}$ CIBER Fisiopatologia Obesidad y Nutrición (CIBERObn), Instituto Salud Carlos III, ... Spain, ${ }^{3}$ Departament de

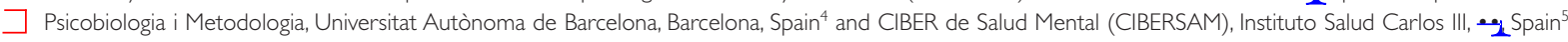

\begin{abstract}
Aims To describe the current situation of gambling in Spain, sketching its history and discussing the regulations and legislation currently in force within the framework of the European Union (EU), and to review the epidemiology of gambling in Spain, the self-help groups and professional treatments available, and their potential effectiveness. Methods A systematic computerized search was performed in three databases (EMBASE, PubMed and PsychINFO, including articles and chapters) and the reference lists from previous reviews to obtain some of the most relevant studies published up to now on the topic of pathologic gambling in Spain. Results Similar to other EU countries, Spain has a high prevalence of pathologic gambling, focused on specific culturally bounded types of gambling. Expenditure in online gaming has risen significantly in the last few years, prompting the Spanish government to draft new legislation to regulate gaming. Conclusions The gaming industry is expected to be one of the fastest growing sectors in Spain in the coming years owing to the rise of new technologies and the development of online gaming.
\end{abstract}

Keywords Pathologic gambling, policy, Spain, treatment.

Correspondence to: Susana Jiménez-Murcia, Pathological Gambling Unit, Department of Psychiatry, Bellvitge University Hospital-IDIBELL, c/Feixa Llarga s/n, 08907 L’Hospitalet de Llobregat, Barcelona, Spain. E-mail: sjimenez@bellvitgehospital.cat Submitted 15 November 2012; initial review completed 14 April 2013; final version accepted 20 April 2013

\section{INTRODUCTION}

In this article the history of gaming in Spain is reviewed from ancient times to the present day, emphasizing the gaming preferences of the population, limitations, regulation and the legislation over time. The cost of gaming in Spain in the context of the current political and economic situation is described. Spain, as one of the European Union (EU) state members, has participated in the commissions on the regulation of online gaming in Europe, which has grown rapidly in the recent years and is predicted to have a greater impact in the near future. Finally, pathologic gambling health-care units and self-help groups in Spain are described.

\section{HISTORY OF GAMBLING IN SPAIN}

From ancient times to the 20th century

Gambling has been an entertainment and leisure activity since ancient times. In fact, there is evidence that prehistoric men liked to gamble; several anthropological studies report instruments and objects that might have been used in gambling, though they have been associated more with magic than with recreation [1]. When the Romans arrived in the Iberian Peninsula in the 3rd century BC they brought with them their taste for gambling of all kinds, as witnessed by the dice made from bones, metal or ivory found in archaeological excavations all over Spain [2,3]. In the Middle Ages, games such as cards, dice and forms of chess were popular, and there were gambling houses where bets could be placed. Later, laws were passed to regulate these establishments and to prevent their proliferation. The legislation also sought to preserve public order, prevent usury and collect taxes for the coffers of the Crown (http://suite101.net/article/juego-y-tahureriasen-la-edad-media-a57029), and, in Spain, gambling establishments were banned from 1387; all types of gambling (apart from the lottery) had to be conducted in private. 
The creation of the State Lottery in the 18th century once again gave Spaniards the chance to gamble legally. This step, intended to raise funds for the public finances, represented a turning point in the history of gambling in Spain; the lottery became highly popular, and its practice in this country is now one of the greatest in the world [4]. With the technological developments of the Industrial Revolution in the 19th century, gambling underwent major changes. New forms, such as roulette, became popular and reached Spain towards the end of the century [2]. It was not until 1922 that a total ban was imposed on gambling, with the closure of casinos and other such venues. The ban remained in force until the end of Franco's dictatorship [5]. Under the dictatorship, gambling was illegal with the exception of the State Lottery, football pools, a charity lottery managed by the National Organization for the Blind (ONCE) and horse racing [6].

\section{The beginning of democracy and gambling in Spain}

This crucial stage in the country's political and social development was resolved peacefully, and the reforms of 1976 implemented policies to bring about democratic changes. Gambling was legalized in February 1977 [7]. In 1981, slot machines were licensed throughout the country, and were quickly installed in places such as bars and restaurants in which there were no restrictions on entry. The result was a significant increase in expenditure on gambling in Spain, and also in the number of gamblers [8].

Between 1977 and 1990, gaming in Spain underwent major expansion. However, with the publication of the first data on gambling expenditure and the emerging awareness of its considerable negative effects [9], especially in the more vulnerable sectors of society, a parliamentary committee was set up to prepare a report on the state of gambling in Spain. Although some measures were taken afterwards, they were insufficient to stop the gambling increase in 1994 [8] and its steady growing trend until the current economic crisis.

\section{The current economic crisis and gambling behavior}

Since 2008, Spain has suffered a profound economic crisis, which plunged the country into recession in 2009, mainly due to a fall of specific productive sectors, the fall in competitiveness compared with other countries, serious problems in the financial sector and high unemployment. Overall, this fall in income and private consumption has had a negative effect on gambling behavior. However, even though the amounts gambled have decreased, particularly in privately managed gambling (i.e. casinos, bingo halls and slot machines), spending on online gambling has risen significantly [7].

In 2011, the expenditure on gambling in Spain totaled $€ 26.6$ billion-2.8\% less than in 2010. In terms of distribution by form of gambling, $37 \%$ was spent on state lotteries, $7 \%$ on the ONCE charity lottery, $35 \%$ on slot machines, $8 \%$ in bingo halls, $6 \%$ in casinos and $7 \%$ online. Excluding online gambling, expenditure would have fallen by about $9 \%$ in 2011 versus only $2.8 \%$ when online gambling is included. In fact, expenditure on online gambling rose by $30 \%$ [7]. Nevertheless, in general terms, the per capita expenditure on gambling began to drop in 2008 as a result of the global economic crisis, and has continued to fall since then [10]. Regarding slot machines, which are highly popular in Spain, the amounts gambled in 2008 exceeded $€ 14$ billion, but by 2011 the figure had fallen below $€ 10$ billion [7], when the possibility of obtaining credit and bank loans became decidedly limited [10].

\section{THE SITUATION OF GAMBLING IN SPAIN: REGULATION AND GAMBLING POLICIES}

The Royal Decree of 25 February 1977 [11] defined the legal framework for criminal, administrative and fiscal aspects of all gaming involving the placing of bets. No substantial changes to the legislation were made until the 2011 Act, passed on May 23 of that year, which included and regulated online gaming. According to the DGOJ [7], even though the state already directly controlled and regulated lotteries, sports betting and charities, the 2011 Act provides the first general legal framework for gambling since 1977. The prime objectives of the legislation are to provide legal security for operators and gamblers, to prevent gambling activity among individuals younger than the of age 18 years, to limit access to people who are excluded from bingo halls, casinos and amusement arcadeseither of their own volition or by court order-and to prevent money laundering and the financing of terrorist activities. Since regulatory and fiscal powers regarding gambling in Spain were transferred to the regional governments, and as this legislation was passed at state level, it also includes the creation of a Gambling Policy Council with representatives of both the central government and the regional governments (autonomous communities).

In a significant change, the Lottery and Gambling Agency, which had been part of the Ministry of Economy and Finance, and had been in charge of the regulation of the gaming industry and the management of state 
lotteries, was abolished by Royal Decree on 11 March 2011. The government decided to divide these two functions and, currently, it is the Directorate General for the Regulation of Gambling [7] that manages the regulation, licensing, supervision, coordination, control and sanctioning of gambling activities at state level. This authority is also responsible for protecting vulnerable groups, developing policies that encourage responsible gambling and promoting research into the area, and assessing its impact on society. The Gambling Policy Council, attached to the DGOJ, set up a working group on 27 June 2011 entrusted with the task of achieving consensus on legal, fiscal and regulatory aspects of gambling in Spain, as well as in relation to advertising, covering offline and online gambling, and other forms of the activity [7], and promoting responsible gambling practice [12].

Consequently, the DGOJ has launched a campaign with the slogan 'Juego Seguro', meaning 'Safe Gambling', coinciding with the granting of gambling licenses in June 2012. The objective of this campaign is to alert citizens of the dangers of illegal gambling sites that are not licensed in Spain, and to make them aware of the benefits of gambling in regulated centers.

\section{GAMBLING REGULATION IN EUROPE: ARE THERE COMMON EU POLICIES?}

The annual revenue from the gaming sector in Europe in 2008 amounted to $€ 75.9$ billion [13]. The gaming industry is expected to be one of the fastest growing sectors in coming years, especially owing to the rise of new technologies and the development of online gaming. Rates of gambling addiction in EU member countries, which have conducted studies of prevalence, range from 0.3 to $3.1 \%$ [14] - the figures for problem gambling being much higher. In November 2011 the European Parliament approved the report by Jürgen Creutzmann, a German Member of the European Parliament, recommending the creation of a single regulation for online gaming in Europe. The report proposed that there should be close cooperation between Member States to develop common policies on consumer protection, fraud prevention and the granting of licenses to operators in the sector throughout Europe. The report also noted that although each State may be given some leeway in their regulation of the offline gaming industry, it is necessary to establish a common commitment to the advancement of minimum Community standards in the case of online gambling, owing to its global nature. Spain has also participated in the calls made by the European Commission and has had several meetings with regulators in France, Italy and the UK.

\section{EPIDEMIOLOGY OF PATHOLOGIC GAMBLING IN SPAIN}

The prevalence of pathologic gambling in the adolescent and adult populations usually ranges between $0.4 \%$ and $7.6 \%$ around the world $[8,15,16]$, with a mean prevalence in adults of $2.2 \%$ [17]. In Spain no national epidemiologic studies have yet been conducted, but regional studies have been carried out in Catalonia, Andalusia and Galicia [8]. A recent epidemiological study in Catalonia, with a sample of 3000 people, identified the following lifetime prevalence of gambling: $2 \%$ at-risk gamblers, $0.5 \%$ problem gamblers and $0.2 \%$ pathologic gamblers [18]. This report also stated that $90.2 \%$ of the Catalan population over the age of 18 years interviewed gambled regularly, $52.2 \%$ had gambled in the past year, and $30 \%$ gambled on a monthly basis or even more frequently. It found that the most popular lifetime forms of gambling were lotteries (84.6\%), football pools $(53.7 \%)$, slot machines $(24 \%)$ and private group betting on sports events. The profile of the average gambler in Catalonia is a male of low economic status aged between 35 and 54 years, with a secondary education and a full-time job. In addition, the study found that problematic and pathologic gamblers were primarily male, between the age of 18 and 34 years, with the behavior beginning around the age of 18 years. Reasons for gambling were its accessibility and the need to escape problems. Finally, increased smoking and substance use was also present.

Earlier studies in other autonomous communities obtained rates of pathologic and problem gamblers ranging from $0.3 \%$ to $1.7 \%$ and $0.2 \%$ to $3.3 \%$ respectively $[6,19]$. Unfortunately, the tools and methodology used differed from study to study. In some, the evaluation procedure consisted of telephone interviews in which screening instruments were administered [18], while in others the interviews were conducted at participants' homes [20]. The type of instrument also used differed from one study to another: some used the South Oaks Gambling Screen [21,22], while others used the National Opinion Research Centre DSM-IV Screen for Gambling Problems $[18,23]$.

\section{THE AVAILABILITY OF SELF-HELP GROUPS AND EVIDENCE OF THEIR EFFECTIVENESS}

Currently in Spain there are several associations for pathologic gamblers (see Appendix 1). However, there is 7 only one state-wide group, known as FEJAR (the Spanish Federation of Rehabilitated Gamblers). This association, founded in 1991, represents 22 organizations across the country, and has worked together with the Directorate 
General of the Regulation of Gambling and European institutions on the design of common legislation for all EU countries.

The programs run by these associations are based on the philosophy of mutual support (people who have had the problem and have managed to overcome it can help others to do the same), and are usually conducted by psychologists, social workers and, occasionally, physicians.

Another model based on mutual aid, but with distinctive features of its own, is Gamblers' Anonymous, the Spanish branch of which applies the same guidelines and objectives as the groups in other countries, characterized by its 12-step, spiritually-based recovery program [24]. Currently, Spain has 32 Gamblers' Anonymous groups in 9 autonomous communities.

Although some associations have written chapters in books describing their therapy approach, few studies have systematically assessed the efficacy of these self-help groups in Spain [25]. Exploratory naturalistic studies reported positive results, with over $30 \%$ rehabilitation rates, $60-75 \%$ abstinence rates of completers and less than 33\% drop-out rates [26-28]. However, as these results have not been published in indexed national and international journals, it is not possible to establish their methodologic validity.

\section{TREATMENT AVAILABILITY FOR PATHOLOGIC GAMBLING AND EVIDENCE OF ITS EFFECTIVENESS}

Since the legalization of gambling in Spain in 1977, the incidence of pathologic gambling has been high. Specialists, staff at hospital centers, gamblers' associations and politicians have become increasingly aware of this disorder, its social implications and the need for treatment. Resources for research, and for psychiatric and psychological care for this disorder have been made available in recent years, especially in outpatient settings. In the late 1980s, the psychiatric service at the Hospital Ramón y Cajal in Madrid and the Department of Psychiatry at Bellvitge University Hospital in Barcelona opened the first units specializing in the treatment of this disorder. More units and health centers for pathologic gambling followed, some of which were already involved in the treatment of substances addictions and extended their care services to include the disorder. By way of example, in Catalonia (in the north-east of the country, with a population of 7565603 inhabitants [29]), there are 10 specific hospital units that deal with pathologic gambling ( 8 centers are for adult population and 2 for adolescents). Moreover, the treatment of pathologic gambling in Catalonia is integrated into the public health system as a psychiatric disorder. Elsewhere in Spain, there are research units attached to clinical psychology departments in universities in Santiago de Compostela, Madrid, Valencia and the Basque Country. Therefore, there is a network of state-funded health-care services throughout the country, which offer free health-care and universal access to all inhabitants. Reflecting the intense activity of these hospital and university units, several handbooks and workbooks on pathologic gambling have appeared in recent decades [30-37]. Since the 1990s several conferences and meetings have been held, bringing together pathologic gambling specialists, patients, families, social workers and other mental health professionals to discuss their experiences, research and programs. In terms of treatment models, therapies based on cognitive behavioral models are the most frequently applied owing to their proven effectiveness in the medium-to-long term [38-44]. Relapse rates between $15 \%$ and $25 \%$ have been observed, and drop-out rates between 15\% and 30\% owing to a range of variables, such as motivation [43], severity [45] and comorbidity associated with the disorder $[41,42]$. These figures are similar to those found in English-speaking countries. Moreover, some follow-up studies using cognitive behavioral therapy approaches have obtained good responses, especially in pathologic slot machine gamblers $[40,41,45]$.

In the context of pathologic gambling therapy, certain cultural issues specific to Spain merit particular attention. For many Spanish people, spending time in a bar (pub) is their only leisure activity. Particularly at certain ages and in certain cultural environments the bar is the social meeting place par excellence and almost all bars have at least one slot machine. Therefore, finding alternative entertainment is a key treatment objective. Some patients feel that the only alternative to going to the bar is to stay home and get bored, so it is essential to involve them actively in their treatment and to encourage them to seek other stimulating recreational activities in which the temptation to gamble is far lower or non-existent.

Some authors have found that the efficacy of the therapy is related to the procedures used [38,42], whereas others have associated success/failure with patients' motivation [43], their neuropsychological functioning [46], or temperament and personality traits [41] In the last 5 years certain new therapeutic strategies based on the new technologies have been analyzed by Spanish researchers [47,48]. Grants for investigating new treatments, risk factors and clinical aspects of pathologic gambling are frequently being funded by the Spanish Ministry of Health (Instituto Salud Carlos IIIFIS), the Ministry of Science and Innovation, and the European Union Framework Programme.

The effort placed by professionals to improve the knowledge of the disorder in Spain has resulted in the 
appearance of many studies on the topic in international journals. These studies, led by Spanish researchers, assess the severity, comorbidity, individual and shared risk factors, and treatment response, along with other factors related to pathologic gambling (e.g. [49-51]).

\section{CONCLUSIONS}

The purpose of this article has been to expose the gambling situation in Spain. Based on a historical perspective, we review the evolution of this activity from antiquity to the present. Likewise, we discuss the regulatory policies of the gambling sector, carried out by the Administration's and the EU's attempts to devise common policies in this area. The regulation of online gaming in Spain has been a milestone in the politics to promote responsible gaming, even though there is still a long way to go. While the gaming sector has suffered a significant recession in the last few years owing to the severe economic situation present throughout Europe, especially in Spain, the monetary expenditure in online gaming has risen significantly. Similar to other EU countries, a high prevalence of pathologic gambling has been observed in Spain. As described, specific culturally bounded types of gambling (e.g. slot machines) are the most frequently used. Finally, the available health-care resources in Spain (both those relying on public health services and self-help groups) and the research being carried out in various hospitals and university groups across the country are presented.

\section{Declaration of interest}

None.

\section{Acknowledgements}

Financial support was received from Ministry of Science and Innovation grant PSI2011-28349), CIBER Fisiología Obesidad y Nutrición (CIBERobn) and CIBER Salud Mental (CIBERSAM), both are initiatives of ISCIII.

\section{References}

1. Petry N. M. Pathological Gambling: Etiology, Comorbidity and Treatment. Baltimore, MD: American Psychological Association; 2005.

2. Fontbona M. Historia del Juego en España. De la Hispania Romana a Nuestros Días [History of Gambling in Spain. From Roman Hispania to Current Day]. Barcelona: Flor del Viento; 2008.

3. Ibáñez A. S., Ruiz J. S. La ludopatía: una 'nueva' enfermedad. Psiquiatría Médica [Pathological Gambling: A 'New' Disease. Medical Psychiatry]. Barcelona: Masson; 2000.

4. Garvía R. Syndication, institutionalization, and lottery play. Am J Sociol 2007; 113: 603-53.
5. ... ABC Heremoteca [Internet]. 2009. Available from:

6. Becoña E. Prevalencia del juego patológico en Galicia mediante el NODS. Descenso de la prevalencia o mejor evaluación del trastorno? [Prevalence of pathological gambling in Galicia with the NODS. Descent of prevalence or best assessment of disorder?] Adicciones 2004; 16: 17384.

7. .... Dirección General de Ordenación del Juego. Memoria Anual-DGOJ, 2011. Madrid: Ministerio de Hacienda y Administraciones Públicas [Dictorate General for the Regulation of Gambling-DGRG. Annual Report 2011. Federal Treasury and Public Administration]; 2012.

8. Becoña E. Spain. In: Meyer G., Hayer T., Griffiths M., editors. Problem Gambling in Europe. Challenges, Prevention, and Interventions. New York: Springer; 2009, p. 281-98.

9. Melchiorre S. Políticas sociales, problemas y experiencias [Social policies, problems and experiences]. In: Blanca D. Croce M., Petri S., editors. Tratado sobre el juego patológico [Handbook of Pathological Gambling]. Buenos Aires: Lugar Editorial; 2012, p. 203-15.

10. Chóliz M., Mazón M. El efecto de la crisis económica sobre el gasto en el juego de azar [The effect of the economic crisis on gambling]. Información Psicológica 2011; 101: 4-13.

11. ....-Boletín Oficial del Estado, núm. 56 de 7 de marzo de 1977, páginas 5302 a 5304 [State Oficial Bulletin, number 56, March 7th, 1977; pag. 5302-5304]; Ref. BOE-A1977-5883; Available at: https://www.boe.es/diario_boe/ (acessed.e.e.e.).

12. ... Boletín Oficial del Estado, BOE [Internet]. 2011 Número 61, 12 de marzo.Sección I. Página 27770. [State Official Bulletin. Number 61, March 12. Section I. Page 27770]. Available at: http://www.boe.es/boe/dias/2011/05/28/ pdfs/BOE-A-2011-9280.pdf (recesse......

13. ... SEC. Green Paper on On-Line Gambling in the Internal Market [Internet]. 2011. Available at: http://eurlex.europa. eu/LexUriServ/LexUriServ.do?uri=COM:2011:0128:FIN:en PDF (2...e.e.).

14. Griffiths M. D., Hayer T., Meyer G. Problem gambling: a European perspective. In: Meyer G., Hayer T., Griffiths M. D., editors. Problem Gaming in Europe: Challenges, Prevention, and Interventions, New York: Springer; 2009, p. ...e..

15. Petry N. M., Stinson F. S., Grant B. F. Comorbidity of DSM-IV pathological gambling and other psychiatric disorders: results from the National Epidemiologic Survey on Alcohol and Related Conditions. J Clin Psychiatry 2005; 66: 56474.

16. Sussman S., Lisha N., Griffiths M. Prevalence of the addictions: a problem of the majority or the minority? Eval Health Prof 2011; 34: 3-56.

17. Muñoz-Molina Y. Meta-análisis sobre juego patológico 1997-2007. Rev Salud Publica (Bogota) [Meta-analysis of pathological gambling 1997-2007. Journal of Public Health] 2008; 10: 150-9.

18. Departament de Salut. Estudi epidemiològic de prevalença del joc patolòic en población adulta de Catalunya (2007-2008). Pla Director de Salut Mental i Addiccions. Generalitat de Catalunya. [Health Department. Epidemiological Study of Prevalence of Pathological Gambling in Adult Population of Catalonia. Guide of Mental Health and Addictions. Government of Catalonia] [Internet]. 2008. Available at: http://www. gencat.cat/salut/depsalut/html/ca/premsa/doc30149.html (acessed.e.c.e.).

19. Becoña E., Fuentes M. J. El juego patológico en Galicia evaluado con el South Oaks Gambling Screen [The pathological

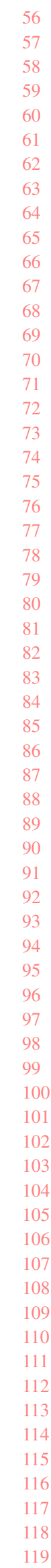


gambling in Galicia assessed with the South Oaks Gambling

20. Becoña E. The prevalence of pathological Gambling in Galicia (Spain). J Gambl Stud 1993; 9: 353-69.

21. Lesieur H. R., Blume S. B. The South Oaks Gambling Screen (SOGS): a new instrument for the identification of pathological gamblers. Am J Psychiatry 1987; 144: 1184-8.

22. Becoña E., Labrador F. J., Echeburúa E., Ochoa E., Vallejo M. A. Slot Gambling in Spain: a new and important social problem. J Gambl Stud 1995; 11: 265-86.

23. Gerstein D., Murphy S., Toce M., Hoffmann J., Palmer A., Johnson R. et al. Gambling Impact and Behavior Study: Report to the National Gambling Impact Study Commission. Chicago: National Opinion Research Center. Chicago; 1999.

24. Jugadores Anonimos jugadoresanonimos.org/

25. Labrador F. J., Fernández-Alaba A. Juego Patológico. En M.A. Vallejo Pareja (Director). Manual de Terapia de la Conducta. Volumen II. Capítulo 3. [Pathological Gambling. In M.A. Vallejo Pareja (Director). Manual of Behavioural Therapy. Volume II, Issue 3.] Madrid: Ed. Dykinson Psicología; 1998.

26. Marín J. V. Azajer: un recurso terapéutico para el tratamiento de la ludopatía. Capítulo 12. In: Echeburúa E., Becoña E., Labrador F. J., Fundación Gaudium, editors. El juego patológico. Avances en la clínica y el tratamiento [Azajer: a therapeutic resource for the treatment of gambling. Issue 12. In: Echeburúa E., Becoña E., Labrador F. J., Fundación Gaudium, coordinators. Pathological Gambling. Progress in the Clinic and Treatment]. Madrid: Pirámide; 2010, p. ...e.

27. Yubero B. La asociación Ekintza Dasalud: un modelo de intervención en ludopatía. Capítulo 13. In: Echeburúa E. Becoña E., Labrador F. J., Fundación Gaudium, editors. El juego patológico. Avances en la clínica y el tratamiento [The Ekintza Dasalud Association: an intervention model in gambling. Issue 13. In: Echeburúa E., Becoña E., Labrador F. J., Fundación Gaudium, coordinators. Pathological Gambling. Progress in the Clinic and Treatment]. Madrid: Pirámide; 2010, p. ...e.

28. Ferrández de la Cruz A. Tratamiento Comunitario de la Ludopatía. Capítulo 14. In: Echeburúa E., Becoña E., Labrador F. J., Fundación Gaudium, editors. El juego patológico. Avances en la clínica y el tratamiento [Community treatment of gambling. Issue 14. In: Echeburúa E., Becoña E., Labrador F. J., Fundación Gaudium, coordinators. Pathological Gambling. Progress in the Clinic and Treatment] [Internet]. Madrid: Pirámide; 2010, p. ....

29. Generalitat de Catalunya. •.... Available at: http://www. gencat.cat/catalunya/cat/index.htm ecesse...e.).

30. Becoña E. La ludopatía [Gambling]. Madrid: Aguilar; 1996.

31. Echeburúa E., Fernández-Montalvo J., Amor P. J. Psychological treatment of men convicted of gender violence: a pilotstudy in the Spanish prisons. Int $J$ Offender Ther Comp Criminol 2006; 50: 57-70.

32. Fernández-Montalvo J., Echeburúa E. Manual práctico del juego patológico [Practical Manual of Pathological Gambling]. Madrid: Pirámide; 1997.

33. González-Ibáñez A. Joc patològic: Una nova addicció [Pathological Games: A New Addiction]. Barcelona: Tibidabo; 1988.

34. Jiménez-Murcia S., Aymamí M. Juego patológico. In: Vallejo J., editor. Introducción a la psicopatología y a la psiquiatría, Screen]. Adicciones 1995; 7: 423-40. $7^{\text {a }}$ Edición revisada [Introduction to Psychopathology and p.

35. Labrador F. J., Fernández-Alba A. Juego Patológico [Pathological Gambling]. Madrid: Síntesis; 2002.

36. Ochoa E., Labrador F. J. El juego patológico [Pathological Gambling]. Barcelona: Plaza y Janés; 1994.

37. Secades-Villa R., Villa-Canal A. El juego patológico: prevención, evaluación y tratamiento en la adolescencia [Pathological Gambling: Prevention, Evaluation \& Treatment in Adolescents]. Madrid: Pirámide; 1998.

38. Echeburúa E., Báez C., Fernández-Montalvo J. Comparative effectiveness of three therapeutic modalities in the psychological treatment of pathological gambling. Behav Cogn Psychother 1996; 24: 51-72.

39. Echeburúa E., Fernández-Montalvo J., Báez C. Prevention in the treatment of slot-machine pathological gambling: longterm outcome. Behav Ther 2000; 31: 351-64.

40. Jiménez-Murcia S., Álvarez-Moya E. M., Granero R. Aymamí M. N., Gómez-Peña M., Jaurrieta N. et al. Análisis de la eficacia de dos modalidades de tratamiento cognitivoconductual grupal para el juego patológico [Analysis of the efficacy of two types of group cognitive-behavioral treatment for pathological gambling]. Psicol Conductual 2005; 13: 497-512.

41. Jiménez-Murcia S., Álvarez-Moya E. M., Granero R. Aymamí M. N., Gómez-Peña M., Jaurrieta N. et al. Cognitivebehavioral group treatment for pathological gambling: analysis of effectiveness and predictors of therapy outcome. Psychother Res 2007; 17: 544-52.

42. Jiménez-Murcia S., Bove F. I., Israel M., Steiger H., Fernández-Aranda F., Alvarez-Moya E. et al. Cognitivebehavioral therapy for pathological gambling in Parkinson's 265-74.

43. Gómez-Peña M., Penelo E., Granero R., Fernández-Aranda F., Alvarez-Moya E., Santamaría J. J. et al. Correlates of motivation to change in pathological gamblers completing cognitive-behavioral group therapy. J Clin Psychol 2012. Ex of print, doi: $10.1002 /$ jelp.21867.

44. Jiménez-Murcia S., Aymamí M. N., Gómez-Peña M. Álvarez-Moya E. M., Vallejo J. Protocols de tractament cognitivoconductual pel joc patològic i d'altres addicions no tòxiques [Guidelines of cognitive-behavioral treatment of pathological gambling and other non-toxic addictions]. Barcelona, Spain: Hospital Universitari de Bellvitge, Departament de Salut, Generalitat de Catalunya; 2006.

45. Jimenez-Murcia S., Aymamí N., Gómez-Peña M., Santamaría J. J., Alvarez-Moya E., Fernández-Aranda F. et al. Does exposure and response prevention improve the results of group cognitive-behavioural therapy for slot machine pathological gamblers. Br J Clin Psychol 2012; 51: 54 71.

46. Alvarez-Moya E. M., Ochoa C., Jiménez-Murcia S., Aymamí M. N., Gómez-Peña M., Fernández-Aranda F. et al. Effect of executive functioning, decision-making and self-reported impulsivity on the treatment outcome of pathologic gambling. J Psychiatry Neurosci 2011; 36: 16575 .

47. Fiménez Murcia S., Fernández Aranda F., Kalapanidas E., Konstantas D., Ganchev T., Kocsis O. et al. Playmancer project: a serious videogame as an additional therapy tool for eating and impulse control disorders. Stud Health Technel Inform 2009; 144: 163-6. Psychiatry, 7th revised edn]. Barcelona: Masson; 2011, disease: a pilot controlled study. Eur Addict Res 2012; 18:

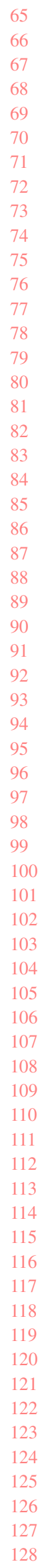

(C) 2013 Society for the Study of Addiction 
48. Fernández-Aranda F., Jiménez-Murcia S., Santamaría J. J., Gunnard K., Soto A., Kalapanidas E. et al. Video games as a complementary therapy tool in mental disorders: PlayMancer, a European multicentre study. J Ment Health 2012; 21 : 364-74.

49. Echeburúa E., Gómez M., Freixa M. Cognitive-behavioural treatment of pathological gambling in individuals with chronic schizophrenia: a pilot study. Behav Res Ther 2011; 49: $808-14$.
50. González-Ortega I., Echeburúa E., Corral P., Polo-López R., Alberich S. Predictors of pathological gambling severity taking gender differences into account. Eur Addict Res 2012; 19: $146-54$.

51. Albein-Urios N., Martinez-González J. M., Lozano O., Clark L., Verdejo-García A. Comparison of impulsivity and working memory in cocaine addiction and pathological gambling: implications for cocaine-induced neurotoxicity. Drug Alcohol Depend 2012; 126: 1-6. 